\title{
Rheumatoid Factor Measurement
}

National Cancer Institute

\section{Source}

National Cancer Institute. Rheumatoid Factor Measurement. NCI Thesaurus. Code C74717.

The determination of the amount of rheumatoid factor antibody present in a sample. 